\title{
Doing Anthropology in a Hostile Environment
}

\author{
Ana Gutiérrez Garza* \\ Department of Social Anthropology, UK
}

*Corresponding author: Ana Gutiérrez Garza, Department of Social Anthropology, UK.
Received Date: July 30, 2019

Published Date: August 29, 2019

\section{Opinion}

It was 10 years ago that I conducted fieldwork for my PhD among women from Latin America who worked in domestic and sex work in London when I started seeing glimpses of the hostile environment that pervades not only in Europe but in various corners of the world. Brexit, Trump, Putin, Bolsonaro, Moody, Salvini, the Janjaweed militia in Sudan, the refugee crisis in Europe, the displacement of thousands of Muslim ethnic minorities in Myanmar, and of course, let's not forget the irreversible consequences of climate change. The list seems to be endless and hopeless. This list, unfortunately, is a reflection of the world in which we live and work nowadays, the world that we study as anthropologists. A world in which proBrexit politicians and Trump's followers had won votes under the rhetoric of anti-immigration, xenophobia, islamophobia and economic precarity. The consequences of this not only affect the socalled western world, but it is used to decimate indigenous peoples across the world along with their livelihoods and territories.

As a non-european anthropologist doing work in Europe with migrants from the so-called third world, I find myself positioned in the middle of a struggle that commenced centuries ago and that is now showing the cracks of painful legacies. The most recent and familiar crack for those of us who live in the UK is of course the Brexit nightmare. I remember just before the referendum back in 2016, I was talking to a friend about it and jokingly, assuming that he was voting in, asked whether he was voting in or out. To my surprise he said out, just like that. I was astonished, frozen by his response. It took me a few seconds to process what I just I heard, as images of Trump, Le Pen, and Farage crossed my mind and clouded my thoughts. I could feel the blood running through my veins and turning my face red. He was the first person I knew who had said that he was voting 'out.' Instead of reacting negatively, I decided to take this opportunity and try to understand what was behind his choice, gain some anthropological perspective on the topic, so to speak. I asked why. His answer, as I feared, went straight to blaming migrants. Migrants, in his view, were not only using and abusing the welfare system, not paying taxes, but he explained how he, as a teacher, could see first-hand how British children were getting left behind due to the increasing presence of migrant children who did not speak English and did not share the same cultural values. 'So, this is about migrants,' I said. He said that unfortunately there were too many, too many. 'What about me? I am a migrant, I am taking up a job that a British person could have. Is it my fault as well?' I asked. Of course, he remained silent. His silence, though, encompassed the deep class and racial underpinnings that discourses like Brexit's have as part of their agenda to recover white supremacy in the West.

Unsurprisingly, this conversation led me to think about my informants and their role in the whole Brexit anti-immigration mess. Which migrants was he talking about? For those who - like some of my informants - do not have documents and live their lives as "illegal"migrants in London, Brexit or no Brexit does not make a difference as they remain invisible and hard to pinpoint. They have increasingly become expendable, worthless, and forced to navigate lengthy draconian legal systems that fracture their inner selves and exploit them in new ways. While the conservative pro Brexit rhetoric stigmatize low-skilled European migrants for taking advantage of the state institutions and the welfare system, there is a parallel anti-illegal migrant's discourse that includes thousands of undocumented non-European migrants. Under these agendas, both groups appear to be on the same boat, both debates echo neoliberal ideologies of deservingness that have enormous impact and resonance in times of austerity and economic crisis. They are a dreadful and alarming reflection of the current state of the world ruled by intolerance, racism, discrimination and new forms of postcolonial exploitation. If a state like the UK is now deporting and denying citizenship rights to people who were brought from the excolonies in order to work in the empire, people grew up in the UK and have their families in the country, like the current case of the Windrush generation, then the future for undocumented migrants like the ones I worked with is nothing but dire. In June 2018 a new 
anti-immigration scandal erupted in the US. Trump reinforced his political agenda and not only separated migrant families (an old immigration policy in the country) but kept children in detention centres, effectively in cages. 'It looks like a zoo', I heard on the Radio while the senator from Texas was being interviewed. This expression made me wonder about Nazi officers visiting concentration camps, probably thinking the same. On top of the horror behind this scene, as a Mexican woman, I cannot help to feel deep anger, frustration and an overwhelming sadness for those people from my country and Central America who are suffering the consequences of rightwing, nationalist, white supremacists' governments in the West.

Despite the current global rhetoric that places migrants as the scapegoats for the failure of states and lack of resources, the presence of these people, the so-called others from the third world, confirm new forms of post-colonial power and produce new social relations. The so-called other, who was relentlessly imagined as the exotic by Europe, is crossing borders fleeing from the long-term consequences of colonial histories. 'We are here because you were there' Sivanandan wisely said. His words resonate in my mind and without doubt had impacted the way in which I conduct myself as an anthropologist doing anthropology of Europe.

Those of us who made the choice to study the amalgamed diversity that populates Europe find that our field sites are postcolonial zones shaped and reshaped by painful legacies that are in continuous expansion. These zones produce and reproduce further inequalities due to on-going global economic forces and states' increasingly rigid immigration policies, which in turn play on and reproduce 'native' racisms. The gap between the rich and the poor is no longer characterised by national geographic locations, it is here, and it widens within our field sites. In order to understand the so-called 'migration crisis' - we, as anthropologists, focus on the effects of capitalism, the impact of neoliberalism and the global systems of domination that consistently 'push and pull' migrants. Then through the detailed ethnographic observation of their everyday lives, we analyse its poignant manifestations and consequences. By doing this, by studying those 'others' within Europe, we revive the old divide between the West and the Rest. We observe this divide during fieldwork by witnessing the inevitable outbreak of various cultural worlds. Despite the so-called transformation and blurring of the boundaries between Western and non-Western societies, our findings tell us otherwise. My own experience while doing fieldwork in London with women migrants confirms that the divide exists on an everyday basis [1]. It is alive. It shapes migrants' livelihoods and subjectivities. It influences migrants' legal realities and social locations and dislocations. The divide is an intrinsic part of the lives of those 'others' who we study as part of our anthropological projects. As a result, we are challenged by the alterity within and by the categories in which such alterity has been placed. How do we make sense of this longstanding divide? Do we ask the right questions to understand the alterity within? Who is the new subject that we observe, dissect and shape by the production of anthropological knowledge? What is our ethical commitment towards the study of the alterity within?
I have to confess that I fear that global discourses of difference subsumed under depoliticized categories like 'multicultural', 'superdiverse' and/or 'transnational' have influenced the way in which we approach this alterity. We are falling into the trap of 'writing culture' along lengthy discussions about racial difference that appeared to be taken for granted and seemed to be silenced in our anthropological reflection. In this current hostile environment, we have the obligation to make explicit the alterity as racialized, gendered, sexualized and culturally specific. If we really want to engage with a critical anthropology of the world in which we live today, I see the need to go back and reassess those questions that post-colonialism, as well as feminism, once asked up front.

Let's go beyond the politics of cultural difference and engage critically with an anthropology of Europe that acknowledges the uncomfortable but unequivocal role that race - with its concomitant dominant white identifications with white supremacy - has played in shaping the post-colonial condition of contemporary Europe and its cultural identity [2]. It is precisely from this powerful postcolonial whiteness that a nondescript, 'superdiversity' is fashioned, essentializing masses of migrants who come from a race-neutral alterity known as the 'third world'. Let's take alterity seriously and reject the naturalization of cultural identity that obscures the complex racial relations of power that keep the 'other' trapped in neutral zones of exclusion. It is not about reifying 'otherness' or simplifying race as a category of difference, but about working against the invisibilisation of race. Only then, by scrutinizing the racial colonial underpinnings of the category of the other - along with its intersections with gender, sexuality, citizenship as well as religious identities - will we be able to develop a critical account of the world in which we live and work today as anthropologists.

If anthropology exists in the encounter with the other and constructs itself and its knowledge through the other, then our discipline entails a revolutionary possibility, the possibility to reach within an out. The revolution within our discipline has always been there, one way or the other. Current discussions and demands on decolonising a discipline that is a result of colonialism and capitalist transformation across the world is, in my view, a good start. However, we must not lose sight of the fact that past colonial encounters and capitalism are not just part of the history that has shaped our discipline, they are emergent and present forms that we are a part of and partake in. We not only need to look reflexively at what we do, what we teach, how we do it and how we write about it, but also need to take a profound look at the privilege position that we have while constructing anthropological knowledge, particularly from the centre. This privilege, in my view, comes hand in hand with the moral obligation to energise education to restore the current political system, to enhance our social relations with humans and non-humans alike, as Haraway Donna [3] proposes, and re-establish human dignity in the wake of climate change and social ruin. As I see it, we have the moral obligation to care for others in such hostile and troubled times and maintain, continue and repair our world so that we can live in it as well as possible. 


\section{Acknowledgements}

None.

\section{Conflict of Interest}

No conflict of interest.

\section{References}

1. Gutiérrez Garza Ana (2019) Care for Sale: An Ethnography of Latin American Domestic and Sex Workers in London. New York: Oxford University Press.
2. De Genova Nicolas (2014) Ethnography in Europe, or an anthropology of Europe? Social Anthropology/ Anthropologie Sociale 22: 293-295.

3. Haraway Donna (2016) Staying with the Trouble: Making Kin in the Chthulucene. Duke University Press, UK. 